\title{
Interdisciplinary Approach to the Study of Scientific Translation
}

\author{
Julia M. Alekseeva* \\ Moscow State Linguistic University \\ 38 Ostozhenka Str., Moscow, 119034, Russia
}

Received 01.07.2014, received in revised form 17.12.2014, accepted 12.03.2015

\begin{abstract}
The paper deals with interdisciplinary analysis of translated scientific texts that, as a rule, oppose to literary ones, in order to gain deeper insight into some main problems touched upon the different linguistic issues, namely, translation and intertext studies, since the textual nature of the former correspond to the basic determination of the latter. This viewpoint provides fresh outlook on these issues and makes the methods originating from other spheres of science applicable for them. Thus, we used prototype method of categorization implemented by cognitive sciences for the reason of its universality unto any issues demanding characterization. In this respect, the key items within this study required for analysis were units of translation regarded as citations, and preciseness or equivalence of translated text (i.e. intertext) to the source or prior text. The latter was also important in terms of examining scientific translations as one of the properties defining this text genre. As a study material, we used scientific abstracts for their brief form and possibility to visually analyse the entire text, which was necessary for this research. Concerning the translation units, the sentence appeared to be the best representative among the other ones varying from words and expressions to transphrastique unities and the whole text. The choice made additionally allows expanding of the analysis to the larger units, up to the text as a whole. The prototypic characteristics of equivalence in translated sentence, according to the literary data on the subject, showed several linguistic demands to be included into the core area of the category. Those sentences, which did not meet the demands, depending on the degree, constituted the areas other than the core one. The results obtained proved the applicability of the interdisciplinary approach used and provided new data to the discourse peculiarities of translated text. Moreover, the present study has extended the knowledge about both translation and intertext, which can be useful for the further studies in this direction.
\end{abstract}

Keywords: interdisciplinary approach, text genre, scientific translation, intertext, prototype approach, categorization, translation units, equivalence, abstract.

Research area: philology.

\section{Introduction}

In linguistics, literary and non-literary texts, particularly, the scientific texts as a genre of the latter, usually contrast with each other. Normally, non-literary and literary texts are respectively characterised by:

1) presence/absence of a direct connection between the communication and human activities;

(C) Siberian Federal University. All rights reserved

* Corresponding author E-mail address: julyulia@gmail.com 
2) absence/presence of aesthetic function;

3) explicit/implicit contents (absence/ presence of an underlying message);

4) aim at certain / ambiguous understanding;

5) reflection of reality/unreality (since literary texts rather show some possible purposely constructed models of reality than reality itself) (Valgina, 2003: 69).

Interlingual translation of texts of any type, as a rule, is focused on preserving of as much from a source text (ST) as possible, including the characteristics, which make the text literary or non-literary. Furthermore, these characteristics become even more important in translated text (TT), because they serve as indicators of the quality of the translation.

Almost all above listed characteristics of non-literary and literary texts indirectly concern the text, except for the explicit or implicit contents of the text. In translated texts, this function can be extended by the preservation of the form (words, expressions, etc.) of these contents in another language, particularly, in scientific texts. Translations of such texts are mostly expected to coincide with ST not only by the sense, but also by the form.

However, there are some limitations due to the differences in the confronting languages that require certain and sometimes significant transformations of varied (from words and expressions to sentences and paragraphs) text fragments, or units of translation, which influence both, the form of ST and its sense.

Nevertheless, the indispensable unit of translation, regardless of all internal differences, is text itself, which is the main study object of various linguistic disciplines. The common object of study makes universal many terms which these disciplines employ.

Thus, any text translated into another language, being a secondary text, shows a complex of recreated fragments of the prior text that in the broadest sense cite it. In this way, TT seems to be a complex of correlating citations (including the whole text as an integrated citation) on a textual basis, i.e. intertext in terms of intertextuality theory.

Initially, R. Barthes, who implemented this term, saw any text as an intertext; "other texts are present in it, at varying levels, in more or less recognizable forms... (Barthes 1981: 39)." Moreover, he indicated that text exists only by virtue of relations between texts, by virtue of intertextuality (Barthes 1989: 428). This phenomenon, according to which "any text is constructed as a mosaic of quotations; any text is the absorption and transformation of another" was previously determined by J. Kristeva (Kristeva, 1986: 37). These concepts form the basis of the intertext discipline.

Linguistics understands the phenomenon of intertextuality as reference, one of the basic properties of the text. In general, linguistic literature describes this property as relatedness of actual (i.e. brought into discourse) nouns and nominative expressions (noun phrases), or their equivalents, to the objects of reality (referents and denotations) (cf. Linguistic Encyclopaedic Dictionary, 1990: 411), which in this case may be another text or prior text.

In this respect, TT most evidently reflects this property: unlike the texts of many other types show this property implicitly; this type of text explicitly refers to ST and its author. Hence, TT can be considered as intertext par excellence.

Therefore, following R. Barthes, who stated that "the citations which go to make up a text are anonymous, untraceable, and yet already read: they are quotations without inverted commas (Barthes, 1977: 160)", the fragments of ST recreated in another language can be well determined as multilayered polycomponent units of translation and/or, at the same time, intertextual 
units or citations. Ultimately, the whole TT, as any other text, is suggested to be a citation of ST "without inverted commas".

The nature of these units and the extent of their transformation, according to which they are categorized below as core and peripheral class members (based on the prototype theory), provide an interdisciplinary approach to the study of such kind of the discourse product as scientific translation by specifying its linguistic characteristics in terms of the metalanguage different from that of translation theory. Notably, nowadays, such kind of approach becomes increasingly applicable in linguistic studies as a whole and translation specifically (cf. Nord, 1997; Halverson, 2002). As C. Rundle points it, "groups of scholars, the majority of whom would probably not define their research paths/careers in terms of translation, are tapping into an interdisciplinary potential that the study of translation offers in ways which do not appear to be taken up within the normal confines of translation studies and within its conventional methodological frameworks (Rundle, 2014: 3).”

\section{Theoretical framework}

Both translation and intertext studies take into account differences in literary and nonliterary texts.

L.L. Neliubin summarized the previous knowledge of the researchers, who dealt with different types of translation, and concluded that the main distinctive feature of the scientific translation compared to the literary one underlies in using many terms and extremely clear and precise presentation of the material lacking, to a certain extent, emotional image-bearing means (Ibid., 2003: 117).

However, recent studies show that the focus of the characterization of scientific translation has shifted from the external coincidence of the scientific material transmitted into another language towards its internal equivalence, i.e. sense, thereby, considering cognitive processes and abilities of technical translator (cf. Risku, 2010).

For instance, L.M. Alekseeva (2002) discusses specifics of scientific text that influence its understanding by translator and means of transmission of a special knowledge to TT.

E.A. Smol'ianina (2012) also studied transmission of a scientific knowledge of the author which she considers as a model based on the type of initial text and its logic. This model should be precisely recreated in TT, rather than ST itself. From this viewpoint, translation of scientific texts means identification of some language units (basic words, explications and associations) and concepts, their comprehension and understanding interconnections between them; then, interpretation of the text in the form of the author scientific knowledge model. At the same time, unlike the interpretation of literary texts allowing multiple versions because of its culture-specific nature and focus on the "broad" audience, the interpretation of scientific texts is limited by logic of a certain scientific knowledge and a scientific cognition as a whole (Ibid.: 222).

In the intertext aspect, any scientific text is a transfer from the known ("old") knowledge to the novel one (cf. Cherniavskaia, 2000). Theoretically based on many prior texts, this text is imperatively related to them with a focus on the prospective inventions. Hence, scientific novelty represents integration of the one's own and somebody else's ideas. Therefore, the intertextuality capable of formulating of a new textual meaning via interaction with other meanings reflects the mechanisms of text generation in science.

According to V.E. Cherniavskaia, who characterized intertextual units in scientific communication, the scientific discourse (original scientific texts) is mainly represented by explicit intertextual means, i.e. the text fragments, which 
are highlighted in graphical symbols following the bibliographical standards, indicating the prior texts in the novel one. These are quotes, reported speech, terms, and so-called background references, which name the author and a year of publication of the prior text without quoting it. At the same time, literary discourse mostly involves implicit intertextual means, which are allusions, headings, etc. (cf. Cherniavskaia, 1999, 2005,2010 ), and as a whole is more diverse in the representation of intertext compared with the scientific discourse.

Indeed, the citation regarded as an absolute reproduction of a fragment from the prior text that is formally marked (normally, as quotation) among other utterances of the text and supplied by the mandatory source reference seems to be the main intertextual mean used in scientific communication. However, this kind of intertextual units was reported (cf. Kuz'mina, 2004) not to be dominating in the scientific discourse for the intertextual interaction that is well provided by less formal units, including the implicit intertextual means, and in the end understanding of the whole text as intertext.

Concerning translation, this statement was supported by E.N. Bazalina. The author, following L.M. Alekseeva in her differentiation of methods of scientific and literary translations depending on their focus, as 'macrocentric' and 'contextcentric', respectively, suggests that translator of scientific texts is not aimed at translation of a certain term or information source; he tries to create a potential dynamic intertextual space (Bazalina, 2011: 39). She supports the idea of Y.M. Lotman that the conventional understanding of invariant substitution of texts in fact is a "psudosubstitution", because intervention of one semiotic sphere into another generates new meanings and new information. On this basis she concludes that unlike the conventional understanding of translation technique, TT does not involve the recreation of ST, but the creation of new text; thereupon, scientific texts can be far more regarded as a meaning-generating mechanism than literary ones (Ibid.: 40).

Previously, this fact was shown by the intertext theorist T.E. Litvinenko stating that evidently, one of the most common situations when recognition of citations and their formal semantic reference with source text takes place almost automatically, without effort, is translated text (Litvinenko, 2002: 151).

Notably, the idea of understanding TT as intertext has been already discussed in modern philological studies.

Thus, yet in 1986, A. Ingberg based on Bakhtin's notion of the dialogic nature of discourse offered another model for thinking about translation indicating, "The concept of intertextuality ... is helpful in rethinking translation theory". Therefore, in the light of intertext theories, translation becomes "dynamic and creative, always just as open as any other discursive activity to interaction among voices, registers, languages, readers, writers and texts, however these are defined (Ibid.)".

Further, P. Torop (1995: 120-121) suggested that in the case of translation, text may combine two intertextual spaces: where it appears and where it is more or less randomly interconnected with other texts, and, thus, transmit TT into the third space making the translation a particularly intense form of intertextual relations.

N.A. Kuz'mina in her works (Kuz'mina, 2001; 2004) attempted to categorize TT having a special culture-significant status as "core intertextual phenomenon".

G.V. Denisova (2001: 124-125), considering intertextuality to be inherent in the culture, determined the translation as a permanent evidence of intertextual relations which function both, within one culture and in a cross-cultural contact. 
Ultimately, some contemporary books on translational studies observe the intertextual aspect of TT (cf. Munday, 2001; Bassnett, 2002).

In summary, the above-mentioned works and the variety of research aspects touching upon the theories of intertext and translation indicate the relevance and a certain interest to the problem of translation in terms of intertext studies. Additionally, they confirm the possibility to use the interdisciplinary approach to the interlingual translation, particularly, scientific.

\section{Statement of the problem}

The existing division into literary and nonliterary texts suggests the similar distinguishing of literary and non-literary (scientific) translation, including its characteristics in the resulted TT. However, the above-mentioned intertext studies show that, despite the obvious differences in characteristics, the scientific texts have much more in common with literary ones in terms of linguistics of text and its representation than it was previously thought. In particular, regardless of the discourse peculiarities both genres of TT rather imply transmission of the sense than the preservation of the original form thus, forming a new text, i.e. intertext. In this case, the difference mostly underlies in text characteristics of the discourse determining its genre (e.g. connection between the communication and human activities, aesthetic function, a certain aim of text and its focus on a certain reader, etc.) that we do not discuss in detail within the framework of this study. Following the basic determination of intertext, we understand any text as intertext, including $\mathrm{TT}$ as its special kind due to the secondary nature demanding reference to ST. It allows us to combine intertext, translation and some other studies, which may contribute to the characterization of types of TT and enhance the knowledge scope of the disciplines used.

\section{Methods}

The analysis of TT as a special kind of intertext allows description of the constituent units based on the comparative interdisciplinary criteria, i.e. as actualized elements of a single prototypical category.

In fact, the prototype approach aimed at identification of "the best representatives of the class" (cf. E. Rosh and E.S. Kubriakova; G. Fauconnier and M. Turner), including those expressed in language and identified as the best representatives of translation, gives a theoretical possibility to include into the category any unit admitted by modern translation studies.

However, the analysis of various translation units at different translation levels showed that it is hardly possible to correctly assess the complex of actualized units below the sentence level within $\mathrm{TT}$ as a whole, and, at the same time, to assess these units as citations within TT as intertext. In addition, sentence is regarded as a universal unit of translation, because the modern linguistics determines sentence (utterance) as a minimal complete communicative unit characterized by predicative and modal meaning. It serves as a key means of generation and expression of thoughts reflecting reality and expression of attitude of a speaker to both, reality and the utterance itself. Due to lexical-grammatical and intonation completeness, sentence comprises the units without independent communicative status. At the same time, sentence is a part of text (text fragment), which is a communicative structure of the next organizational level (cf. O.S. Akhmanova and N.S. Valgina). Moreover, this unit is more observable and much easier to operate (both, translate and analyse), unlike larger units, e.g. transphrastique unities, which allocation may have risk of significant loses and meaning transformations typical of free translations.

Overall, the structuring of the prototypical category of the units of translation at a level of 
sentence allows us to combine their examining with the analysis of the constituting them morphemes, words and expressions. It also enables transition of observation to the level of transphrastique unities and, finally, text, which is necessary for the study of characteristics of TT taking into account its genre and, additionally, assessing it as intertext.

Concerning intertext units (citations), previously, T.E. Litvinenko (2008: 133, etc.) formulated the structure of their prototypic category. However, this category characterizing the prototypic citation was based on the classification of the units identified in conventional intertexts which i) include not only exact or transformed citations, but also the fragments which are not recognized by the reader (even the author) as "somebody else's words"; ii) originate in different citation sources (several prior texts), as a rule, in the same language; iii) contain citations of various language/text levels that may lack predicative status.

In TT as a special kind of intertext, the main citation source is a totally "somebody else's" prior text, which is ST. Furthermore, unlike the conventional intertexts referring to prior texts in the same language, TT deal with different language and ethno-cultural systems. For this reason, we have formulated another interpretation of the prototype within the category of intertext units represented by sentences of TT.

The most relevant characteristics of citation of those formulated by T.E. Litvinenko is exact reproduction of the elements from the prior text (Ibid: 133). However, in contrast to conventional intertexts, exact reproduction of the elements from ST in TT is not actually achievable. Therefore, an optimal similarity between TT and ST that is maximum possible under specific conditions seems to be a relative value (Garbovskii, 2007: 213-214). In this case, the modern translation theory mostly uses the term equivalence instead of exactness, since, the items and quantities of the same value and worth or in any respect consistent with others and capable of expressing or substituting them appear to be equivalent (Ibid.).

An overview of linguistic and translation studies literature on form and content-based parameters of exactness and ways of its achievement allows us to determine the core criteria of the category or prototypic units as follows:

i) exactly reproducing predicative status of the element of the prior text (i.e. status of an independent utterance);

ii) preserving the modality of the element of the prior text;

iii) equivalently transmitting the meaning of the element of the prior text via lexicalgrammatical means of the target language (interlingual synonymy).

It should be noted that prototypic units of this category admit transformations and substitutions determined by lexical-grammatical system of the target language (e.g. presence/absence of an article, gender, types of verbs, differences in using a certain type of preposition with verbs, punctuation or narrative specifics of the target language, etc.).

Additionally, the prototype of the category of translation/intertext units may involve such semantic and pragmatic characteristic as adequate transmission in TT sentences of the ST intertextual insertions, if any. In scientific discourse, they are quotes, citations, references, etc. However, even in scientific discourse it is not possible for translator to consider this criterion all the time due to some linguistic and/or discourse specifics of a certain TT. For example, in case when the intertextual insertion have no equivalent in target language.

Due to interlingual transformations, the sentences modified in TT can more or less differ 
from the core criteria; hence, depending of the degree of transformations, the category structure requires allocation of additional non-core areas expanding its range. The units which lacked at least one of the above core criteria we categorized as near-core or peripheral.

\section{Discussion}

As a material for this study, we used multiple abstracts and their translations included into the issues of the scientific journal "VESTNIK of Moscow State Linguistic University" (Issue 9 (615) Linguistics, 2011 and Issue 9 (642) Linguistics, 2012). The choice was determined by the fact that abstracts, as a type of text, is a brief description of the basic text, including its main issues and, in some cases, their structure (cf. P. Brandes, 2001: 67). Abstracts reflect the main idea of the basic text. At the same time, distinguished as an independent type of text (or even secondary text, along with TT), abstract can be examined separately from the basic text. Normally, it is short and written in simple sentences. Therefore, it serves a good material for not only analytical, but also the visual observation of both, units of translation or intertext, i.e. translated sentences, and the text of a translated abstract (i.e. intertext) as a whole. Laconic form of abstract also provides observation of many different text materials of the same type and have a deeper insight into this issue.

Another reason for choosing abstract as study object was the fact that they are usually translated be ST authors themselves; hence, the study is free of the presence in translation the additional cognitive space of another person represented by a translator. Thereby, at the initial stage of this study the results obtained would be more clear.

Moreover, the linguistic thematic of the journal issue allowed better understanding of the sense of the examined text material without additional turning to specialized sources necessary in other scientific fields.

\section{Core Area}

In the course of the analysis, we found that the examples of the units corresponding to the stated core criteria in scientific discourse were mostly the titles of the texts, which was rather predictable: ПРОБЛЕМА УНИВЕРСАЛЬНЫХ СТРАТЕГИЙ В ПЕРЕВОДЕ - UNIVERSAL STRATEGIES PROBLEM IN TRANSLATION; ТЕРМИН-РЕАЛИЯ КАК ПЕРЕВОДЧЕСКАЯ ПРОБЛЕМА - REALIA-TERM AS A TRANSLATION ISSUE; ДИСТРИБУТИВНОЕ УПОТРЕБЛЕНИЕ ЧИСЛОВЫХ ФОРМ: ТРУДНОСТИ ПЕРЕВОДА - ТНЕ DISTRIBUTIONAL USAGE OF THE NUMBER FORMS: DIFFICULTIES OF TRANSLATION; К ВОПРОСУ О ПРЕДМЕТНОЙ СИТУАЦИИ В ПЕРЕВОДЕ. ПОДХОДЫ К ОПИСАНИЮ ПРЕДМЕТНОЙ СИТУАЦИИ - ON DENOTATIVE SITUATIONS IN TRANSLATION. WAYS OF DESCRIBING DENOTATIVE SITUATIONS; CЕМИОТИЧЕСКИЙ АСПЕКТ ВЫСКАЗЫВАНИЯ КАК ЕДИНИЦЫ ОБЩЕНИЯ И ПЕРЕВОДА - ТНЕ SЕМIOTIC ASPECT OF THE UTTERANCE AS A COMMUNICATION AND TRANSLATION UNIT; ПЕРЕВОД КИНОФИЛЬМОВ КАК ОТДЕЛЬНЫЙ ВИД ПЕРЕВОДА - MOVIЕ TRANSLATION AS A SEPARATE TRANSLATION TҮРЕ; АНГЛИЦИЗМ В РЕКЛАМНОМ ТЕКСТЕ: ЗНАК ГЛОБАЛИЗАЦИИ? - ANGLICISMS IN ADVERTISEMENT TEXTS: SIGN OF GLOBALIZATION?; ПОСЛЕДОВАТЕЛЬНЫЙ ПЕРЕВОД: ПЕРЕВОДЧИК КАК ИДЕАЛЬНЫЙ СЛУШАТЕЛЬ CONSECUTIVE INTERPRETING: INTERPRETER AS A PERFECT LISTENER; ПРОИЗВОЛЬНОСТЬ ВЫБОРА КОДА ПРИ ПЕРЕВОДЕ ARBITRARINESS OF CODE CHOICE IN TRANSLATION. 
Nevertheless, among all examined texts the titles meeting the core demands of the category were not dominating. Interestingly, only few units possessed core characteristics within the texts, for example, the following pair of sentences with slight punctuation changes as specifics of target language: Они различны лексико-семантический, стилистический, прагматический, узуальный и m. n. - They are various: lexical-semantic, stylistic, pragmatic, usual, etc.

Obviously, considering differences in lexicalgrammatical system of the target language, all these examples preserve the relatedness of the content of the utterance from ST (prior text) to the reality in a form of a sentence (unlike word combination), which means the exact reproduction of predication in TT. Modality in these unites may be represented by various language means, both grammatical (e.g. forms of the mood) and lexical (e.g. modal words and particles), and intonation (e.g. represented in text by interrogation mark) shows relatedness of the author to this content, which the preservation of modality implies. Finally, all examples equivalently transmit the meaning by lexical and grammatical means of the target language.

\section{Near-core area}

Near-core area consisted of the sentences characterized by insignificant transformations and changes in the predicative structure and/or modality of those from the prior text that to some extent affected the pragmatics (i.e. languagecontext relations) of the utterance.

This classification area also included many translated title-sentences with some insignificant transformations. For example, there is the effect on the pragmatics of the utterance in the title РЕПРЕЗЕНТАЦИЯ ГЕТЕРОГЕННОГО КОНЦЕПТА «ЖЕНЩИНА» В ИСПАНСКИХ ПАРЕМИЯХ - REPRESENTATION OF THE
HETEROGENEOUS CONCEPT «WOMAN》IN SPANISH PROVERBS. In this unit, the word paroemia used in ST was changed in TT by a more general one, proverb, because in English this term is mainly associated with parables, than with proverbs implied in that study. However, all these words in a certain context are synonyms. Hence, we observe a synonymic substitution aimed at better understanding of the study object in TT.

Another title shows the example of slight grammatical and lexical changes which do not affect the meaning of the transmitted utterance: КОНЦЕПТУАЛЬНЫЕ

ОСНОВАНИЯ КУЛЬТУРНЫХ ЯЗЫКОВЫХ ЗНАКОВ CONCEPTUAL BASIS OF CULTURE-BOUND $L A N G U A G E$ SIGNS. There are the obvious transformations in number (from plural to singular), caused by the common usage in target language, and parts of speech (from adjective to noun) accompanied by a lexis addition which do not influence the pragmatics of the unit, but simply turns again the noun into the form of adjective. Thus, according to Collins Cobuild Advanced Learner's English Dictionary (2008) (cited in ABBYY Lingvo $\times 5$ electronic dictionary), -bound combines with nouns to form adjectives for different pragmatic purposes.

The following example, ОБ АСИММЕТРИИ ОЗНАЧАЮЩЕГО И ОЗНАЧАЕМОГО ЯЗЫКОВОГО ЗНАКА: ИССЛЕДОВАНИЯ ЯЗЫКОВОГО СОЗНАНИЯ БИЛИНГВА - ON ASYMMETRY OF THE SIGNIFIER AND THE SIGNIFIED LINGUISTIC SIGN: THE RESEARCH EXPERIENCE OF LANGUAGE CONSCIOUSNESS OF THE BILINGUAL PERSON., may reflect some unnecessary transformations in the translation units. In one case, there is the grammatical change in word order of attributive construction without change in the meaning, though it could be preserved in TT using the preposition of. In 
another case, there is an addition of a word person, which do not influence the pragmatics of the text, but could be omitted, since the word bilingual in English is also used in the form of a noun.

In addition to the above-mentioned change in word order of attributive constructions the title ГЕЛЬВЕЦИЗМЫ ВО ФРАНЦУЗСКОМ ЯЗЫКЕ И ПРОБЛЕМЫ ПЕРЕВОДА - HELVETISMS IN FRENCH: TRANSLATION ISSUES Shows an example involving punctuation, which slightly changes modality of the utterance and, hence, the pragmatics of the unit observed. Thus, the copulative conjunction used in ST is substituted by the colon, "usually preceding an explanation or an example of what has gone before, a list, or an extended quotation" (Collins English Dictionary, 2006 cited in ABBYY Lingvo $\times 5$ electronic dictionary).

On the contrary, the unit ПРОБЛЕМА «ЯЗЫК И СТИХ" В ПОЭТИЧЕСКОМ ПЕРЕВОДЕ - THE PROBLEM $\underline{\text { OF }}$ LANGUAGE AND VERSE IN $\underline{T H E}$ TRANSLATION OF POETRY illustrates the change omitting the inverted commas in ST and adding the preposition of with no effect on modality, meaning and, finally, pragmatics of TT. The same preposition is also added due to the grammatical changes in word order and resulting transformation of some parts of speech in the attributive construction, although this change was not necessary because the language system of TT has the equivalent attributive construction. It is rather a syntactic synonymy of the constructions without meaning and/or pragmatics changes in the unit.

Similar changes and transformations were also observed in the sentences within the main body of the text. Additionally, there could be some synonymic substitutions, both lexical and grammatical, including syntactical ones that do not affect the unit in TT compared to ST. For eхаmple, Помимо лексической составляющей дистрибутивные конструкичи по-разному представлены в структурном плане. Besides the lexical form the distributional constructions are structurally represented in a different way. In terms of pragmatics, this kind of transformation and the above changes in word order of attributive constructions concern shift of so-called topic-comment (thematic-rhematic) relation, i.e. actual division of the utterance. However, again these shifts are not crucial in these cases, since they do not distort the meaning of the element of the prior text.

\section{Near-peripheral area}

Sentences with significant transformations in the predicative structure and modality of the prior text, and lexical-grammatical changes leading to semantic and pragmatic modifications of the utterance comprised the near peripheral area of the category.

The units included in the near peripheral area might have similar to the near-core area grammatical (i.e. syntactical modifications, changes in number or time, etc.), lexical (synonymous substitutions, omitting or addition of words, etc.), and pragmatic (actual division shifts, etc.) transformations, but with obvious semantic differences between comparable units of ST and TT.

For instance, in the translated sentence B cmambe paccмampuвается диалог как одно из ключевых понятий философской антропологии и герменевтики. - Dialog $\underline{\text { is }}$ оnе of the key notions of philosophic anthropology and hermeneutics., the word fragment about paper was omitted, hence, the actual division was shifted from the consideration of this problem in this very paper to the problem in general. This shift was amplified with the substitution of a comparative conjunction meaning serving as by the auxiliary to be bearing the affirmative meaning. Obviously, these transformations 
influenced significantly the pragmatics of the unit.

The actual division shift accompanied by perceptible changes in pragmatics of the comparable ST element may also result from some syntactical modifications, e.g. division (parcelling) or joining of sentences, i.e. alteration of predicative status of the element of the prior text. Parcelling implies that unlike the joined sentence, divided sentences meet their own communicative demand and pragmatics, especially, when supplemented by other lexical and/or grammatical transformations during translation, as in the following pair of sentences: В статье предлагается модель учебника по устному переводу, цель которого - обучение на материале интервью двустороннему переводу как профессиональной деятельности. - The article describes a concept of a manual of interpretation. It $\underline{\text { aims }}$ to develop the skills of dialogue interpretation (DI) as a professional activity on the bases of an interview (dialogue), identifving several stages of mastering DI. Grammatical transformations in this example concern the substitution of the passive voice by the active voice and a noun by a verb due to the differences in representation of scientific discourse in confronting languages. Thus, using verbal forms with passive lexical and grammatical characteristics of time, person and number is typical for the scientific discourse in the Russian language (cf. Stylistic Encyclopaedic Dictionary of the Russian Language). At the same time, many English scientific writing guidelines recommend avoiding using passive grammatical and lexical means, in particular passive voice (cf. Alvin, 2014). However, these changes concern the discourse characteristics of the target language, hence, they should be considered and applied by translator, and they do not change much the pragmatics of the source fragment by themselves. At the same time, this example also shows some lexical substitutions of the words in TT, the meaning of which is not equivalent to that in ST, and some specifying additions in the translated unit that lack in the source one. Thus, all these transformations evidently affect the pragmatics of the whole utterance.

Along with additions, there could be some omissions in the observed units. For example, С иелью обеспечения адекватности и прагматической эквивалентности перевода переводчик использует разныле стратегии в зависимости от того, какой вид переводческой деятельности он осуществляет. - Adequacy can be reached by means of employing various strategies. The pragmatics of the translated utterance in this case becomes more general compared to the source one. Additionally, the omitting also shifts the actual division of the source unit from translator to adequacy.

The area also included the sentences with significant semantic changes due to the substitutions of certain lexical and grammatical components that had a wide generalized meaning in ST by those of more narrow specified meaning in TT, e.g., В данной статье рассматривается лексико-тематическая организация текста, семантические поля и терминосистемы и их актуализация в тексте в виде тематических сеток и терминополей, которые могут содержать случайные лакуны. - This article examines lexical and subject structure of the text, semantic fields and term systems and their textual forms: subject grids and term fields which may contain equivalent-lacking words and word combinations - the lexical "lacunes". Furthermore, the implementation of the additional punctuation marks rather for pragmatic reasons (the column meaning i.e. [see above] and inverted commas to indicate indirect meaning of the word lacunes originating from Latin lacuna pool, cavity, from lacus - lake (Collins English 
Dictionary, 2006; Oxford Dictionary of English, 2010 cited in ABBYY Lingvo $\times 5$ electronic dictionary)) than for grammatical requirements of the target language amplifies the pragmatic modifications of the ST utterance transmitted in TT.

Another type of units within the near peripheral area is TT sentences some components of which were transmitted in a form of the paraphrase, thus, more or less compensating loss or change of some semantic elements in the course of translation. For instance, in the translation of the ST sentence Каждая лексикосемантическая группа языковых единии характеризуется ограниченным набором базовых концептуальных составляюших. The language units belonging to the same semantic group are based on a limited set of basic conceptual constituents., the paraphrase simply explains the meaning of the source utterance than preserve its formal structure.

Paraphrase of the translated sentence, Перевод можно назвать преобразованием в рамках определенных кодов. - Translation is a transformation within certain codes., represents a reduction by omitting one of its semantic elements, which the author considered to be irrelevant in TT. However, with this omission, the suggestive form of the source utterance has transformed into the affirmative one, therefore, changing its pragmatics.

In some cases, the detected paraphrases of TT showed a combination of means, i.e. the same TT sentence might have some relatively insignificant reductions and additions accompanied by significant grammatical and lexical transformations transmitting of the meaning in a different way compared to the ST sentence. For example, Статья посвящена описанию модели языкового знака, учитывающей предыдущие состояния означаемого и означающего. The paper presents a model of the language sign including reference to its previous modes (as a unity of the signifie and the signifiant) in the language system.; Однако нельзя сбрасывать сосчетов индивидуальный стиль переводчика, который подлежит лингвопереводческому исследованию. - The point, however, is that a translator's individual style also needs to be considered., etc.

The title units included into this area showed the same characteristics as the ones within the text. Thereby, generally we observed a reduction or addition of lexical means (e.g. $\underline{\boldsymbol{K}}$ ВОПРОСУ $\boldsymbol{O}$ ПЕРЕДАЧЕ ДЕНОТАТОВ В ПЕРЕВОДЕ - DENOTATIVE TRANSITION IN TRANSLATION; ПРИЕМЫ ФОРМИРОВАНИЯ ПЕРЕВОДЧЕСКИХ НАВЫКОВ И КОМПЕТЕНЦИЙ В ПРОЦЕССЕ РАЗВИТИЯ ВТОРИЧНОЙ ЯЗЫКОВОЙ ЛИЧНОСТИ DEVICES TO DEVELOP THE TRANSLATION SKILLSANDCOMPETENCESINTHE PROCESS OF SECOND LANGUAGE ACQUISITION $\underline{\mathbf{C O R}}$ THROUGH THE DEVELOPMENT OF THE SECOND LANGUAGE PERSONALITY), etc.) and significant synonymic substitutions (е.g. ОПЫТ СОЗДАНИЯ УЧЕБНИКА ПО УСТНОМУ ПЕРЕВОДУ - CONCEPT ОF AN INTERPRETATION MANUAL, etc.), or combination of both (e.g. УЧET ФAKTOPA ЯЗЫКОВОГО И СИТУАЦИОННОГО КОНТЕКСТА ДЛЯ АДЕКВАТНОЙ ПЕРЕДАЧИ ЛЕКСИЧЕСКИХ ЕДИНИЦ ПРИ ПЕРЕВОДЕ ЭКОНОМИЧЕСКИХ ТЕКСТОВ С РУССКОГО ЯЗЫКА НА АНГЛИЙСКИЙ ЯЗЫК LANGUAGE AND SITUATIONAL CONTEXT EMPLOYED TO ENSURE ADEQUATE RENDERING OF LEXICAL UNITS IN TRANSLATIONS_OF ECONOMIC TEXTS FROM RUSSIAN INTO ENGLISH), all accompanied by various grammatical transformations changing the pragmatics of the comparable ST unit.

There were also title units in a form of paraphrase. For example, in TT of title 
sentence ЛЕКСИЧЕСКАЯ ЛАКУНАРНОСТЬ И ЛЕКСИКО-ТЕМАТИЧЕСКАЯ ОРГАНИЗАЦИЯ ТЕКСТА - LEXICAL “LACUNES” IN TEXTS OF DIFFERENT SUBJECT STRUCTURE, the word ЛАКУНАРНОСТЬ was changed by other related word "LACUNES" representing lexical transformation at morphological level. Moreover, this transformation was complicated by the change in number and some punctuation additions that totally influence not only the transformed word alone, but also the general sense of the whole utterance. Another change in this unit is also a paraphrase operating at lexical and grammatical level of the ST title and preserving, to some extent, in TT only its general meaning.

Notably, despite the main characteristic of this area implying significant changes in the meaning of the transformed utterances due to lexical and grammatical changes and expectance that the predicative structure and pragmatics of titles is mostly preserved in TT for they normally reflect the main subject of the study in scientific discourse, the observed text material showed many title units referred to this area caused by actual division shift in TT.

Overall, it changes the pragmatics of the utterance making TT from the very beginning a new text (i.e. intertext) which title reflects somewhat different subject of the study than ST (e.g. ОСОБЕННОСТИ ПЕРЕВОДА И НЮАНСЫ ПРЕПОДАВАНИЯ АНГЛИЙСКИХ ФРАЗОВЫХГЛАГОЛОВ В ЯЗЫКОВОМВУЗЕENGLISH VERBS: DETAILS OF TRANSLATION AND PECULIARITIES OF TEACHING).

Moreover, in some cases all sentences of the abstract, including the title, were classified as near-peripheral. Thereby, the transition from the language level of sentence to the of the whole text represented here as an abstract, indicates that pragmatics of such TT is significantly changed, which allows us to regard this text as a new one not only in terms of another language, but also towards ST simultaneously being the prior text. Even though we attempt to make a reverse translation of this TT into the source language, the pragmatics of the resulted text would be significantly different from the initial ST.

\section{Peripheral area}

Finally, the peripheral units of the category involved the TT sentences with transformations and changes that distort dramatically the predicative structure of ST, including additional sentences in TT with no referent in prior text or vice versa omitting of the whole sentences which present in ST.

The observed study material showed the following examples of predication distortion of the corresponding ST fragments allowing considering these units to be peripheral: Переводческая топонимика обеспечивает эстетическую объективацию процесса межъязыковой коммуникации. - His outsideness ensures him a kind of aesthetic position, like an author's attitude towards his characters.; B cтатье рассматриваются вопросы лексической и семантической сочетаемости при переводе. - The most fundamental problem involved in the theory and practice of translation from one language into another consists in achieving adequacy between the source language and the target language.; Переводчик должен не только учитывать правила сочетаемости лексических единии, но и анализировать семантику слова в речи, что влечет за собой ряд переводческих трудностей $и$ является причиной переводческих трансформаций. - If the purport of a lexical unit cannot be adequately rendered at a word-to-word pattern, situational context comes into play.; Сформулированные в ходе анализа выводы могут быть актуализированы в магистерских 
программах российских высших учебных заведений, осуществляющих подготовку профессиональных переводчиков. - The analysis pays attention to the variety of approaches in structure and content of training programmes to get equivalent diplomas. These TT units are obviously different both, in lexicalgrammatical structure and in semantics of ST and TT utterances compared.

However, some text fragments were not subjected to comparison at all, since either ST or TT simply lacked this fragment. For instance, we found that the following sentences were omitted in TT: Программы рассматриваются c точки зрения структуры, содержания, трудоемкости курсов и модулей и путей достижения заявленных иелей. -; Отношения коммуникантов в тексте и роль получателя информации диктуют использование средств диалогизачии. -.

On the contrary, the some sentences were added in TT, - In particular, shifts and techniques involved in restructuring lexical units in the target language are discussed.; - The article was prepared without co-authors.; - In particular the author investigates the nature of translation norm as a part of its common translation approaches and means of translation adequacy.

These omissions/additions rather distort pragmatics not of a certain utterance, but that of entire ST or prior text.

In some cases, all sentences of the translated abstract were had nothing to do with those of ST, thus, making the whole TT peripheral relative to its original. Solely, the name of the author and hitherto knowledge of a text as a translated version of an abstract, as well as a common topic discussed in both ST and TT might hint of the reference of TT to ST, because neither their external (lexical and grammatical structure) nor internal (semantic) characteristics were comparable.
In fact, the transition to the larger textual level up to the whole text as a unit of translation or intertext, based on the categorization of its constituting sentences, was the next stage of the categorization analysis. Similar to the nearperipheral area, we observed some abstracts all sentences of which had characteristics allowing us to attribute them to the peripheral area and, thereupon, the entire abstract can be regarded as peripheral relative to ST or prior text.

Interestingly, the categorization of the abstracts at text level showed only one abstract where characteristics of all sentences in TT belonged to the near-core area, and none abstract which TT could be considered absolutely core in its structure towards ST. The category of those abstracts which TT had a mixture of categorized sentences according to their characteristics was determined by a certain area dominating among all sentences of TT.

In summary, the whole corpus of analysed scientific abstracts has shown that the major part of their translated versions was categorized as near-peripheral relative to ST or prior text.

Therefore, despite the above mentioned conventional notion of translation theory that scientific translation should possess 'extremely clear and precise presentation of the material' relative to ST, which we attributed to the three indicators (exact reproduction of predicative status of the element of the prior text; preservation of the modality of the element of the prior text; equivalent transmission of the meaning of the element of the prior text via lexical-grammatical means of the target language), we observed significant lexical-grammatical transformations that influence the pragmatics of the text at various levels, from sentence to the entire text.

\section{Conclusion}

Various linguistic disciplines, which regard text in different aspects and terms, but still 
examine the same study object, allowed us to combine these aspects, compare the terms used by certain disciplines, and, therefore, apply interdisciplinary approach to the translated text of scientific genre that, as a rule, is considered to contrast with literary translation in representation of the material, principally because of the discourse specifics reflected in text by lexicalgrammatical means.

Apart from theory of translation, the approach involved intertextuality theory, since the secondary nature of TT characterized by its indispensable reference to ST suggests the possibility to regard it as a special kind of intertext, let alone the wide-sense original understanding of any text as intertext.

Furthermore, categorization or prototype method initially implemented within the cognitive sciences (psychology, linguistics, etc.) has provided text analysis due to presence in translation theory of ambiguous views on units of translation and preciseness or equivalence of TT to ST, particularly unto scientific translation, that are necessary for comparison of confronting texts. Previously, applying of this method was also useful for the intertext studies. These data has contributed to this work, which in turn has enhanced the category of intertext types so far existing within the framework of the theory of intertextuality and, probably, has given new insight into some problems of translation theory.
The result obtained has confirmed the recent studies indicating that along with literary translation, scientific translation also possesses mainly internal equivalence unlike the expected external one, despite the differences of text genres, i.e. scientific translation also focuses on meaning generation coincided with the original text rather than its form preservation. Evidently, this meaning generation by means predominantly different from ST and, at the same time, its obvious reference to the latter creates new text or intertext simply as linguistic object regardless of the language.

In addition, dominance of the units categorized within a certain area varying in abstracts analysed has shown different degree of equivalence to ST, which, similarly to literary texts, implies its more diverse intertextual representation than it seemed for scientific translations.

Finally, since the analysis has not shown the dependence of scientific translation from the equivalence to ST in its external form, this approach is capable of assessing an equivalence degree of the transmitted 'author scientific knowledge model' (see above), which could be useful for the future studies in this field

\section{Acknowledgments}

The author thanks Dr, Prof T.E. Litvinenko for guidance and assistance in preparing of this work.

\section{References}

1. ABBYY Lingvo $\times 5$ Russian version: electronic dictionary (2011).

2. Akhmanova, O.S. Slovar' lingvisticheskikh terminov [Glossary of linguistic terms]. Moscow, Sov. Entsiklopediia, 1969. 608 p.

3. Alekseeva, L.M. Spetsiphika nauchnogo perevoda [Specifics of scientific translation]. Perm, Perm University Publ., 2002. 125 p.

4. Alvin, L.P. (2014). The passive voice in scientific writing. The current norm in science journals. Journal of Science Communication, 13(1), A03.

5. Barthes, R. From Work to Text. In Image Music Text, trans. Stephen Heath. London, FontanaPress, 1977. pp. 155-164. 
6. Barthes, R. Izbrannye raboty: Semiotika. Poetika [Selected works: Semiotics. Poetics]. Moscow, Progress Publ.,1989. 615 p.

7. Barthes, R. Theory of the Text. In Untying the Text: A Post-Structuralist Reader. Ed. R. Young. London: Routledge and Kegan Paul, 1981. pp. 31-47.

8. Bassnett, S. Translation Studies. London: Routledge, 2002. 176 p.

9. Bazalina, E.N. (2011) $K$ voprosu o metodike obucheniia perevodu nauchnogo stilia $v$ angliiskom i russkom tekstakh [On the method of training of scientific translation in English and Russian texts]. Vektor nauki TGU, 3(6), 38-41.

10. Brandes, P., Provotorov, V.I. Predperevodovedcheskii analiz teksta (dlia institutov $i$ fakul'tetov inostrannykh iazykov) [Pre-translational text analysis (for foreign language institutions and departments)]. Moscow, NVI-TEZAURUS, 2001. 224 p.

11. Cherniavskaia, V.E. Interpretatsiia nauchnogo teksta [Interpretation of scientific texts]. Moscow, URSS, 2005, 2010. 128 p.

12. Cherniavskaia, V.E. Intertesktual'nost' kak tekstoobrazuiushchaia kategoriia v nauchnoi kommunikatsii (na materiale nemetskogo iazyka) [Intertextuality as text-generating category in scientific communication (case study: German language)]. St. Petersburg, 2000. 352 p.

13. Cherniavskaia, V.E. Intertekstual'noe vzaimodeistvie kak osnova nauchnoi communikatsii. [Intertextual interaction as the basis of scientific communication] St. Petersburg, 1999. 209 p.

14. Denisova, G.V. Intertekstual'nost' i semiotika perevoda [Intertextuality and semiotics of translation]. Tekst. Intertekst. Kul'tura: Sbornik dokladov mezhdunarodnoi nauchnoi konferentsii (Text. Intertext. Culture: Proceedings of international scientific conference). Moscow, Azbukovik Publ., 2001. pp. 112-128.

15. Denisova, G.V. V mire interteksta: iazyk, pamiat', perevod [In the world of intertext: language, memory, translation]. Moscow, Azbukovik Publ., 2003. 298 p.

16. Fauconnier, G. and Turner, M. Conceptual Blending, form, and meaning. Cognitive Semiotics, special issue of Recherches en Communication. Ed. P. Fastrez, 2003. 19. pp. 58-86.

17. Garbovskii, N.K. Teoriia perevoda [Theory of translation]. Moscow, MGU Publ., 2007. 543 p.

18. Halverson, S. (2002) Cognitive models, prototype effects and 'translation': the role of cognition in translation (meta)theory. Across Languages and Cultures, 3 (1). pp. 21-43

19. Ingberg, A. The enigma of the translator: a poststructuralist reading of theories of translation. Purdue University, 1986. 313 p.

20. Kharitonova, E.A. Kontseptualizatsiia kak strategiia perevoda nauchnogo teksta: Na materiale russkogo i angliiskogo iazykov [Conceptualization as strategy of translation of scientific texts. Case study: English and Russian languages]. Perm, 2006. 197 p.

21. Kristeva, J. Word, Dialog and Novel. In The Kristeva Reader. Ed. Toril Moi, New York: Columbia University Press, 1986. pp. 34-61.

22. Kuz'mina, N.A. (2001) Phenomen khudozhestvennogog perevoda v svete teorii interteksta. [Phenomenon of literary translation in the light of the theory of inter-text]. Tekst. Intertekst. Kul'tura: Sbornik dokladov mezhdunarodnoi nauchnoi konferentsii (Text. Intertext. Culture: Proceedings of the international scientific conference). Moscow, Azbukovik Publ., 2001. pp. 97-111.

23. Kuz'mina, N.A. Intertekst I ego rol'v protsessakh evolutsii poeticheskogo iazyka [Intertext and its role in the evolution of poetic language]. Moscow, Editorial URSS, 2004. 272 p. 
24. LES - Linguisticheskii entsiklopedicheskii slovar' [Linguistic Encyclopaedic Dictionary]. Ed. V.N. Iartseva. Moscow, Sov. Entsiklopediia, 1990. 683 p.

25. Litvinenko, T.E. Intertekst $v$ aspektakh lingvistiki I obshchei teorii teksta [Intertext in the aspects of linguistics and the general theory of text]. Irkutsk, IGLU Publ., 2008. 308 p.

26. Litvinenko, T.E. Problema peredachiznacheniia intertekstual'nykhedinits vkhudozhestvennoi proze [The problem of transferring the sense of intertextual units in prose]. Russkii iazyk $v$ krugu mirivykh iazykov i iazykovoe planirovanie $v$ XXI veke (traditsii, innovatsii, perspektivy): materialy mezhdunarodnoi konferentsii (Russian language among world languages and language planning in XXI century (traditions, innovations, percpectives): Proceedings of the international conference). Irkutsk, IGLU Publ., 2002. pp. 150-155.

27. Munday, J. Introducing translation studies: Theories and applications. London: Routledge, 2001. $222 \mathrm{p}$.

28. Neliubin, L.L. Tolkovyi perevodovedcheskii slovar' [Explanatory dictionary of translation theory terms]. Moscow, Flinta: Nauka, 2003. 320 p.

29. Nord, Ch. Translating as a purposeful activity: Functionalist approaches explained (Translation theories explored). Manchester: St. Jerome Publishing, 1997. 160 p.

30. Risku, H. (2010) A cognitive scientific view on technical communication and translation: Do embodiment and situatedness really make a difference? Target, 22(1). pp. 94-111.

31. Rundle, Ch. (2014) Theories and methodologies of translation history: the value of an interdisciplinary approach. The Translator, 20(1). pp. 2-8. doi: 10.1080/13556509.2014.899090

32. Smol'ianina, E.A. (2012) Osobennosti strategii perevoda nauchnogo teksta [Strategy specifics of translation of scientific texts]. ISOM, 3, pp. 219-222.

33. Stilisticheskii entsiklopedicheskii slovar' russkogo iazyka [Stylistic Encyclopedic Dictionary of the Russian Language]. Ed. M.N. Kozhina. Moscow, Flinta: Nauka, 2006. 696 p.

34. Torop, P. Total'nyi perevod [Total translation]. Tartu, Tartu University Publ., 1995. 220 p.

35. Valgina, N.S. Teoriia teksta [Text theory]. Moscow, Logos, 2003. 250 p.

36. VESTNIK of Moscow State Linguistic University. Issue 9 (615) Linguistics, 2011.

37. VESTNIK of Moscow State Linguistic University. Issue 9 (642) Linguistics, 2012. 


\title{
Междисциплинарный подход
}

\section{к изучению научных переводов}

\author{
Ю.М. Алексеева \\ Московский государственный \\ лингвистический университет \\ Россия, 119034, Москва, ул. Остоженка, 38
}

В статье анализируется научный перевод, который в силу дискурсивных особенностей, как правило, противопоставляется переводам литературных произведений. Цель настоящей работы заключается в расширении представления о тексте перевода, текстуальные характеристики которого соответствуют понятию интертекста в его классическом понимании. Это позволяет применять к изучению перевода, в частности научного, междисциплинарный подход для решения вопросов в отношении жанрового различия с литературными переводами, а также других вопросов, обсуждаемых в рамках как теории перевода, так и теории интертекстуальности. Так, применение такого подхода позволяет взглянуть на переводоведческие проблемь единиц перевода, а также эквивалентности в интертекстуальном аспекте. Последняя проблема особенно важна и в свете рассмотрения научных переводов в соответствии с предъявляемым к ним требованиями жанра. $B$ отношении теории интертекстуальности рассматриваемый объект позволил расширить категорию видов интертекста и дополнить его признаки. В качестве материала для исследования были взяты переводы аннотаџий к научным публикациям, признаваемых в качестве самостоятельных законченных текстов. Лаконичность их изложения позволила проанализировать большое количество такого рода текстов для получения более корректных результатов. Анализ проводился на основе прототипического метода категоризации, первоначально применяемого в когнитивных исследованиях. Согласно этому методу объекты, объединённые общим признаком, но различные по содержанию, классифицируются либо как устойчивое ядро, соответствующее определённым прототипическим признакам, либо как периферия при наличии отличий от прототипа. Проведённое исследование подтвердило применимость как прототипического метода, так и в целом междисииплинарного подхода к исследуемым объектам. Выводы, сделаннье в результате анализа, свидетельствуют о том, что дискурсивные особенности текста при переводе не распространяются на его интертекстуальность. Иными словами, набор интертекстуальных средств, используемых при переводе научных текстов, не менее разнообразен, чем в литературных переводах. Полученные результаты могут быть полезны для дальнейших исследований в этом направлении.

Ключевые слова: междисичиллиарный подход, стиль текста, научный перевод, интертекст, прототипический подход, категоризация, единицьы перевода, эквивалентность, аннотация.

Научная специильность: 10.00.00 - филологические науки. 